\title{
DIAGENETIC/ANCHIMETAMORPHIC CHANGES ON THE PROTEROZOIC GLAUCONITE AND GLAUCONY FROM THE PARANOÁ GROUP, MID-WESTERN BRAZIL
}

\author{
EDI MENDES GUIMARÃES ${ }^{1}$, BRUCE VELDE ${ }^{2}$, STEVE HILLIER $^{3}$ AND ELIZABETH NICOT $^{4}$
}

\begin{abstract}
Petrographic, X-ray and chemical studies were made on glauconies from sandstones belonging to the same tectonic and Arraphic glauconitic sandstones were recognized, i.e., white feldspatic, green-reddish ferric and green-grayish calcitic sandstones, with different content glauconitic sandstones were recognized, t.e., white feldspatic, green-reddish ferric and green-grayis. In each sandstone, glauconite shows a non-expansible structure, as well as high contents of $\mathrm{Al}$ and $\mathrm{K}$, but other chemical features and mineralogical assemblages vary from one rock to another. Differences found in chemical composition of the glauconies from different rocks and their mineralogical evolution are attributed to lithologically dependent changes since all the studied sandstones have the same origin, and have undergone the same diagenetic/anchimetamorphic conditions.
\end{abstract}

Keywords: glauconite, diagenesis, anchizone, Proterozoic, mineralogy, chemistry, sedimentology.

INTRODUCTION In the study of green phyllosilicates, the terms glauconite and glaucony are employed with different meaning. In this paper the term glaucony (plural glauconies) is used in a morphological sense for green fine-grained minerals, either micaceous or in pellets. The term glauconite is used for a dioctahedral mica, containing $<5 \%$ expandable layers and a structural formula intermediate between a celadonite and an illite (Millot 1964, Odin and Matter 1981).

Glaucony has been considered an indicator of low sedimentation rate and a diagnostic feature for transgressive cycles. Amorosi (1995) emphasizes that a reliable interpretation of the stratigraphic sequence of glaucony-bearing units requires information on spatial distribution, maturity and conditions of formation of the glauconies. Glaucony maturity is indicated mainly by their chemical composition and stiucture, both of which also change during diagenetic evolution.

The percentage of expandable layers in glauconite, as in illite, decreases when K-content increases (Burst 1958, Odin and Matter 1981) following diagenesis intensity (Hower 1961). Strickler and Ferrell (1990) show that $\mathrm{Fe}$ substitution for $\mathrm{Al}$ is indicative of less intensive diagenesis, while Al substitution for $\mathrm{Fe}$ and $\mathrm{Si}$ has been detected by Ireland et al. (1983), under high grade diagenetic conditions.

Distinct physical-chemical marine environments have been suggested as responsible for different chemical compositions of glauconite (Porenga 1967, Berg-Madsen 1983). On the other hand, Odin $(1975,1988)$ demonstrates that chemical variation is a function of the maturity, that is, the stage of glauconitization process. During this process a young, $\mathrm{K}$-poor glauconitic smectite is progressively altered to a K-rich glauconitic mica. However, deep burial and metamorphism could also change the composition of glauconite.

The influence of lithology during diagenesis over both the expandable layer content of glauconite (Hower 1961) and its chemical composition (Bentor and Kaster 1965) has been suggested, but little attention has been given to this subject.

Clearly, it is important to understand to what extent each of these three controls - depositional environment, degree of diagenesis and adjacent deposits - may influence the composition and structure of glauconite. It is also necessary to establish to what extent the environmental signatures can survive diagenesis and metamorphism.

This paper concerns the mineralogical and chemical variation of glauconite during diagenesis/anchimetamorphism as a function of lithology. The studied glauconite and associated minerals come from the Cabeceiras region (GO). In Midwestern Brazil (Fig.1), they belong to three glauconitic sandstones mineralogically differentiated, in the same stratigraphic/tectonic level of the Paranoá Group (Guimarães 1997), a Proterozoic sequence.

MATERIALS AND METHODS Glauconitic sandstones samples were obtained from outcrops in the region of Cabeceiras (GO). Polished thin sections of samples were studied by both conventional petrographic microscopy and microprobe. Fine-grained fraction $(<2$ $\mathrm{mm}$ ) for the X-ray diffraction analyses (XRD) was separated by gravity settlings. XRD was performed using a Philips machine with $\mathrm{Cu}$ radiation. Conventional methods for clay mineral studies were used: air-drying, solvation by ethylene-glycol vapor for 12 hours at $60^{\circ} \mathrm{C}$ and heating at $490^{\circ} \mathrm{C}$ for 4 hours. To estimate the proportion of expandable layers, experimental diffraction patterns were compared with diffraction profiles calculated using Reynolds' NEWMOD (1985).

Microprobe analysis were made on polished thin sections, using a CAMECA Camebax microprobe with operating conditions of $15 \mathrm{kV}$, beam current of 5 to $10 \mathrm{~mA}$ and counting time of $10-15 \mathrm{sec}$. per element with a spot size of about $2 \mathrm{~mm}$. Analyzed phyllosilicates are green fine-grained glaucony grains, as well as illite and chlorite which seem to have partially replaced the glauconitic grains. Structural formulae for glauconite and illite analyses were re-calculated on the basis of 44 negative charges and assuming all iron to be ferric. Analyses that gave structural formulae with octahedral sum of 4.0 ( \pm 0.05 ) were selected as glauconite and illite, but values over 4.05 were assumed to be intergrowths of illite or glauconite and chlorite. Chlorite was calculated on the basis of 56 negative charges and assuming all iron as ferrous. Analyses with high $\mathrm{Na}, \mathrm{Ca}$ and $\mathrm{K}$ contents and low octahedral occupancy have been interpreted as smectite, or intimate intergrowths of mica and chlorite, or even mixed-layer clay minerals.

Chemical determination of the whole rock (WR) composition was made by colorimetry ( $\mathrm{Si}, \mathrm{Al}, \mathrm{Ti}$ and $\mathrm{P}$ ); atomic absorption $(\mathrm{Mn}, \mathrm{Mg}$ and $\mathrm{Ca}$ ); emission spectrometry ( $\mathrm{Na}$ and $\mathrm{K}$ ). Total $\mathrm{Fe}$ and $\mathrm{Fe}^{+2}$ were determined by titrimetry while the $\mathrm{Fe}^{+3}$ was calculated by the difference.

RESULTS The three Paranoá glauconitic sandstones show different sedimentary structures, textures and mineralogical composition (Table 1). Glauconies in each one of the sandstones also show distinct features, but partial replacements by quartz and feldspar are frequent in all the samples.

Table 1 - Mineralogical composition of the Paranoa glauconitic sandstones.

\begin{tabular}{|c|c|c|c|}
\hline ROCKS & \multicolumn{3}{|c|}{ ORIGIN OF THE MINERALS } \\
\hline & Detrital & Intrabasinal & $\begin{array}{c}\text { Diagenetic } \\
\end{array}$ \\
\hline $\begin{array}{l}\text { White } \\
\text { sandstone }\end{array}$ & $\begin{array}{l}\text { Quartz } \\
\text { Feldspar } \\
\text { Clay mincrals } \\
\text { Accessorics }\end{array}$ & $\begin{array}{l}\text { Glauconite } \\
\text { Clay minerals }\end{array}$ & $\begin{array}{l}\text { Quartz: overgrowth, replacement, } \\
\text { cement. } \\
\text { Feldspar: replacement. } \\
\text { Glauconite/Fc-illite: alteration. } \\
\text { Clay minerals: alteration. }\end{array}$ \\
\hline $\begin{array}{l}\text { Green-reddish } \\
\text { sandstone }\end{array}$ & $\begin{array}{l}\text { Quart/ } \\
\text { Clay mincrals } \\
\text { Accessorics }\end{array}$ & $\begin{array}{l}\text { Glauconite } \\
\text { Clay mincrals } \\
\text { (?) } \\
\text { lron oxides }\end{array}$ & $\begin{array}{l}\text { Quartz: replacement, cement. } \\
\text { Feldspar: replacement. } \\
\text { Glauconite: alteration. } \\
\text { Clay minerals: alteration. } \\
\text { lron oxides: replacement, cement. }\end{array}$ \\
\hline $\begin{array}{l}\text { Green-greyish } \\
\text { sandstone }\end{array}$ & $\begin{array}{l}\text { Quart: } \\
\text { Feldspar (?) } \\
\text { Micas } \\
\text { Clay minerals } \\
\text { Accessorics }\end{array}$ & $\begin{array}{l}\text { Glauconite } \\
\text { Carbonate } \\
\text { Clay mineral (?) } \\
\text { Iron oxides }\end{array}$ & $\begin{array}{l}\text { Quartz: overgrowth, replacement, } \\
\text { cement. } \\
\text { Feldspar: replacement. } \\
\text { Glauconite: pseudomomphism. } \\
\text { Chlorite: alteration, replacement. } \\
\text { Carbonatc: replacement, cement. } \\
\text { Clay minerals: alteration. } \\
\text { Iron oxides: replacement, cement. }\end{array}$ \\
\hline
\end{tabular}




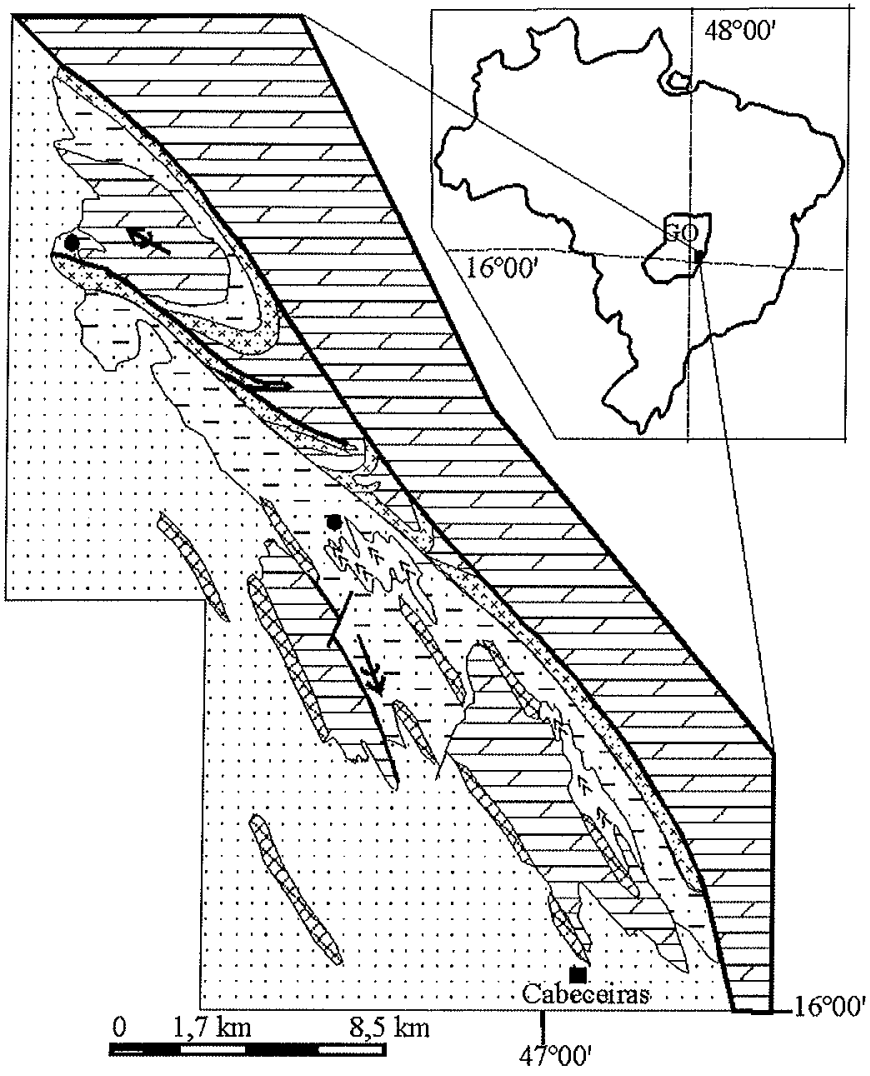

- Localization of the analysed glauconitic samples.

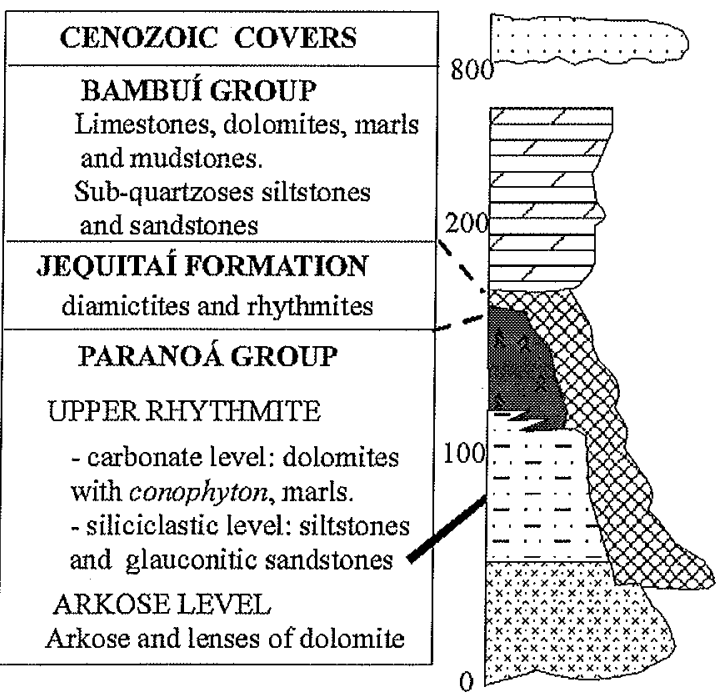

Figure 1 - Geological setting and simplified lithostratigraphy of the Cabeceiras area, with the localization of the samples investigated in the present study.

1- White sandstone, the poorest glauconitic level (glaucony grains $<$ $10 \%$ ), is a massive bedded, moderately sorted, medium-grained feldspathic $(15 \% \mathrm{KF})$ rock. Glauconies are notably uniform pale green pellets, consisting of internally randomly arranged clay aggregates. These glauconies are interpreted as parautochthonous grains.

2- Green-reddish sandstone is the richest glauconitic unit ( $>50 \%$ glauconite). The rock consists of green-reddish, medium-grained, thin layered sandstone with minor red shales. Glauconies are dark, rarely pale green, fine-grained pellets, intensely compacted more or less parallel to bedding oriented. This glauconitic layer is assumed to be an autochthonous level. Prismatic reddish Fe-oxides are formed around the edges of some pellets. Opaque iron oxide cement account for more than $10 \%$ of the rock and replaces some glaucony grains.
3- Green-grayish sandstone has lost much of its primary mineralogical and textural characteristics, under of post-depositional processes. The rock is medium-grained sandstone made up of alternating quartz-rich and glaucony-rich layers. Both layers contain the same minerals, but the phyllosilicates are much more abundant in the glauconitic layers. Glauconies occur either as fine-grained pellets or between the cleavage plane of detrital micas, as well as pseudomorphs. These glauconies seem to be autochthonous, but some grains in the quartz rich layers can be parautochthonous. In this paper only the glauconitic pellets are discussed. They are either dark or pale green, fine-grained randomly oriented aggregates, but some compacted pellets show small recrystallized lamellar particles, oriented with the bedding. In addition to replacements by quartz and feldspar, which occur in all three sandstones, the pellets are sometimes replaced by calcite and chlorite. The glauconitic layers were subjected to extensive styllolitization, and the glauconite replacement and recrystallization are more frequent than in the quartz layers.

X-ray patterns (fig. 2) show typical basal reflections for glauconite and illite from samples of the three glauconitic sandstones.

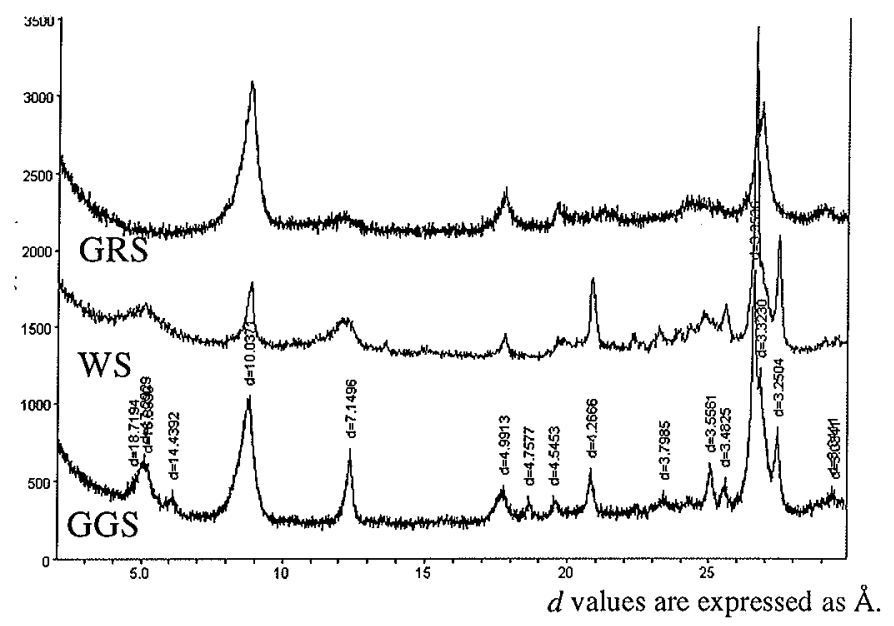

Figure 2 - X-ray patterns of glycolated oriented fine fraction from greenreddish (GRS), white (WS) and green-grayish (GGS) sandstones.

The sharp diffraction peaks and their comparison with computer calculated diffraction profiles indicate a well-ordered $10 \AA$ phase with less than 5\% expandable layers. Small amounts of kaolinite in the white and green-reddish sandstones as well as smectite in the former are interpreted as products of weathering. The green-grayish sandstone does not seem to be weathered, and smectite could represent an intermediate phase between glauconite and chlorite. Quartz and feldspar occur in variable amounts in all X-ray patterns, but chlorite appears only in the green-grayish sandstone.

Electron microprobe analyze (Table 2) demonstrated that the composition of the Paranoá glauconite varies from one sandstone to another, although they are high $\mathrm{K}$ and aluminous species, in all samples. Their K-content averages 1.6 per formula unit and shows only slight variation, but for each sandstone, charge balance of glauconite is achieved by a different combination of tetrahedral and octahedral substitution (fig. 3). In the white sandstone the glauconitic mineral has a tetrahedral and octahedral charge averaging 0.9 and 0.7 respectively. The glauconite in the green-reddish sandstone shows the opposite distribution with less than 0.7 charge in the tetrahedral position and octahedral charges averaging 1.0. In the green-grayish sandstone the charge distribution is intermediate to the two types.

In the white sandstone, glauconies, which are always pale green pellets, constituted by fine-grained phyllosilicates, show an almost constant chemical composition like a ferric illite, with a general formulae: $\mathrm{K}_{1.6}(\mathrm{Ca}, \mathrm{Na})_{0.04}\left(\begin{array}{lllll}\mathrm{Al}_{2.38} & \mathrm{Fe}_{0.91} & \mathrm{Mg}_{0.7} & \left(\mathrm{Si}_{7.03}\right. & \mathrm{Al}_{0.97}\end{array}\right)$ $\mathrm{O}_{20}(\mathrm{OH})_{4}$.

${ }^{20}$ Glauconies in the green-reddish sandstone are often dark-green, compacted pellets and again show a little variation in chemical composition. They have a tetrahedral composition like standard 
Table 2 - Whole rock (WR) composition (WE\%) of glauconitic sandstones, examples of chemical composition and structural formula of glauconite and minerals in the white (WS), green-reddish (GRS) and green-grayish (GGS) sandstones.

\begin{tabular}{|c|c|c|c|c|c|c|c|c|c|c|c|c|c|c|c|c|c|c|c|c|c|}
\hline Oxides & WR & \multicolumn{3}{|c|}{ Glcuconite-WS } & WR & \multicolumn{3}{|c|}{ Glauconite - GRS } & WR & \multicolumn{3}{|c|}{ Glauconite-GGS } & \multicolumn{3}{|c|}{ Illite } & \multicolumn{3}{|c|}{ Mixed-layers (?) } & \multicolumn{3}{|c|}{ Chlorite } \\
\hline $\mathrm{SiO}_{2}$ & 84.7 & 51.8 & 52.2 & 53.1 & 66.1 & 53.6 & 52.9 & 52.4 & 79.3 & 52.4 & 53.5 & 53.5 & 49.6 & 48.2 & 47.3 & 43.3 & 40.1 & 33.8 & 27.6 & 26.7 & 25.6 \\
\hline $\mathrm{TiO}_{2}$ & 0.2 & 0.00 & 0.2 & 0.00 & 0.5 & 0.1 & 0.0 & 0.0 & 0.3 & 0.1 & 0.1 & 0.1 & 0.6 & 0.2 & 0.1 & 0.2 & 0.1 & 0.1 & 0.0 & 0.0 & 0.0 \\
\hline $\mathrm{Al}_{2} \mathrm{O}_{3}$ & 7.4 & 21.0 & 19.8 & 20.4 & 9.9 & 12.5 & 13.5 & 17.5 & 8.4 & 18.9 & 18.8 & 16.6 & 22.9 & 25.9 & 17.2 & 16.4 & 17.0 & 18.0 & 17.5 & 17.5 & 18.0 \\
\hline $\mathrm{Fe}_{2} \mathrm{O}_{3}$ & 0.8 & 8.9 & 9.2 & 9.3 & 11.8 & 12.8 & 12.0 & 10.1 & 0.8 & 8.6 & 8.6 & 10.4 & 6.3 & 6.0 & 10.2 & 12.6 & 16.9 & 23.3 & & & \\
\hline $\mathrm{FeO}$ & 0.2 & & & & 0.7 & & & & 0.8 & & & & & & & & & & 25.9 & 24.2 & 25.8 \\
\hline $\mathrm{MgO}$ & 0.3 & 3.4 & 3.7 & 3.6 & 1.8 & 5.4 & 5.2 & 4.4 & 0.8 & 4.4 & 4.5 & 5.2 & 3.5 & 3.1 & 5.1 & 7.4 & 9.0 & 12.9 & 14.2 & 16.0 & 14.6 \\
\hline $\mathrm{CaO}$ & 0.1 & 0.1 & 0.1 & 0.1 & 0.1 & 0.1 & 0.1 & 0.1 & 1.0 & 0.1 & 0.1 & 0.1 & 0.2 & 0.3 & 2.1 & 0.1 & 0.2 & 0.2 & 0.2 & 0.8 & 0.1 \\
\hline $\mathrm{Na}_{2} \mathrm{O}$ & 0.1 & 0.1 & 0.1 & 0.0 & 0.5 & 0.1 & 0.0 & 0.0 & 0.2 & 0.0 & 0.1 & 0.1 & 0.2 & 0.3 & 0.1 & 0.0 & 0.2 & 0.0 & 0.1 & 0.1 & 0.1 \\
\hline $\mathrm{K}_{2} \mathrm{O}$ & 4.2 & 9.4 & 9.6 & 9.2 & 4.9 & 9.4 & 9.3 & 9.0 & 6.6 & 9.4 & 9.4 & 9.6 & 9.5 & 10.3 & 7.9 & 6.9 & 4.4 & 2.2 & 0.4 & 0.4 & 0.2 \\
\hline $\mathrm{H}_{2} \mathrm{O}$ & 1.9 & & & & 3.9 & & & & 1.4 & & & & & & & & & & & & \\
\hline Sum & 99.8 & 94.8 & 94.9 & 95.8 & 100. & 93.9 & 93.6 & 93.6 & 100. & 93.9 & 95.2 & 95.6 & 92.9 & 94.3 & 90.2 & 86.9 & 88.0 & 90.7 & 85.9 & 85.3 & 84.5 \\
\hline $\mathrm{Fe}^{+2} / \mathrm{Fe}^{+3}$ & 0.3 & & & & 0.05 & & & & 1.01 & & & & & & & & & & & & \\
\hline
\end{tabular}

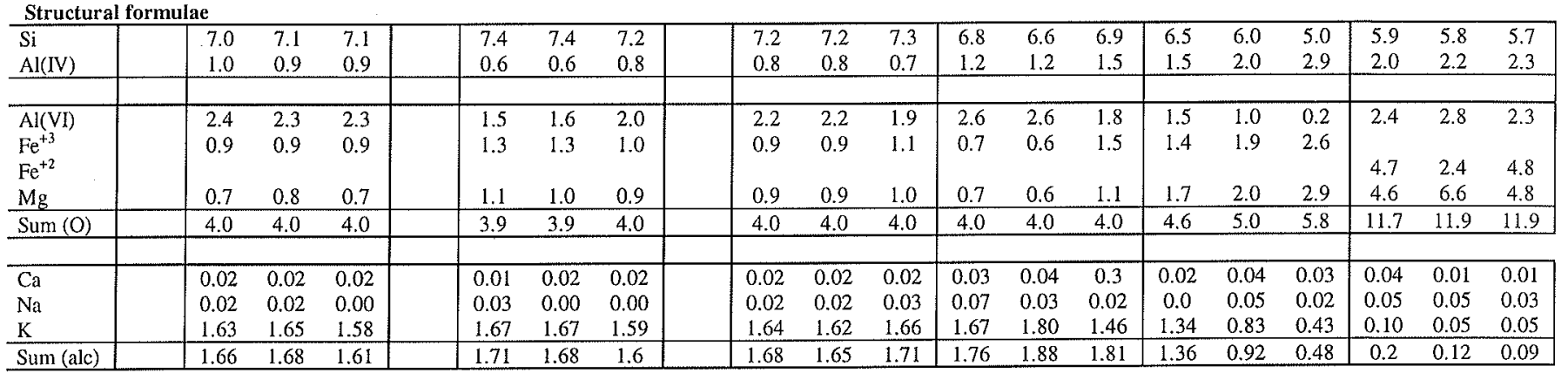
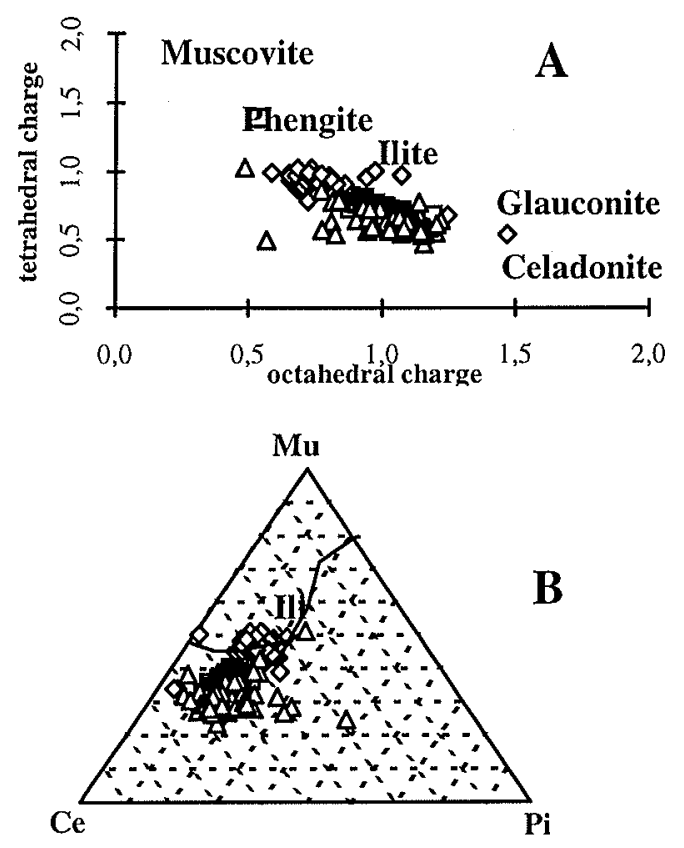

Figure 3 - Charge distribution (a): in white sandstones, the charge of glauconite is like illite; in the green sandstones the charge of glauconite falls in the glauconite field $(b)$. Mu-muscovite; $C e$ - celadonite; Pi-pyrophyllite. Symbols as in figure 4.

glauconite mica $\left(\mathrm{Si}_{7.4} \mathrm{Al}_{0.6}\right)$, but in the octahedral site Fe-content is relatively low (1.2-1.3) and appears to be compensated by both high contents of $\mathrm{Al}(1.4-1.8)$ and of $\mathrm{Mg}$ (near 1.0).

Glauconies in the green-grayish sandstone present various morphology, color, optical properties and variable chemical composition. However, no clear relationship between morphology and chemical composition was found. All data presented here correspond to glauconitic pellets as well as associated illite and chlorite. Analytical data plotted in a MR-R3-R2 diagram (Velde 1985a) indicate two distinct chemical trends (fig. 4). First, glauconite tends towards an
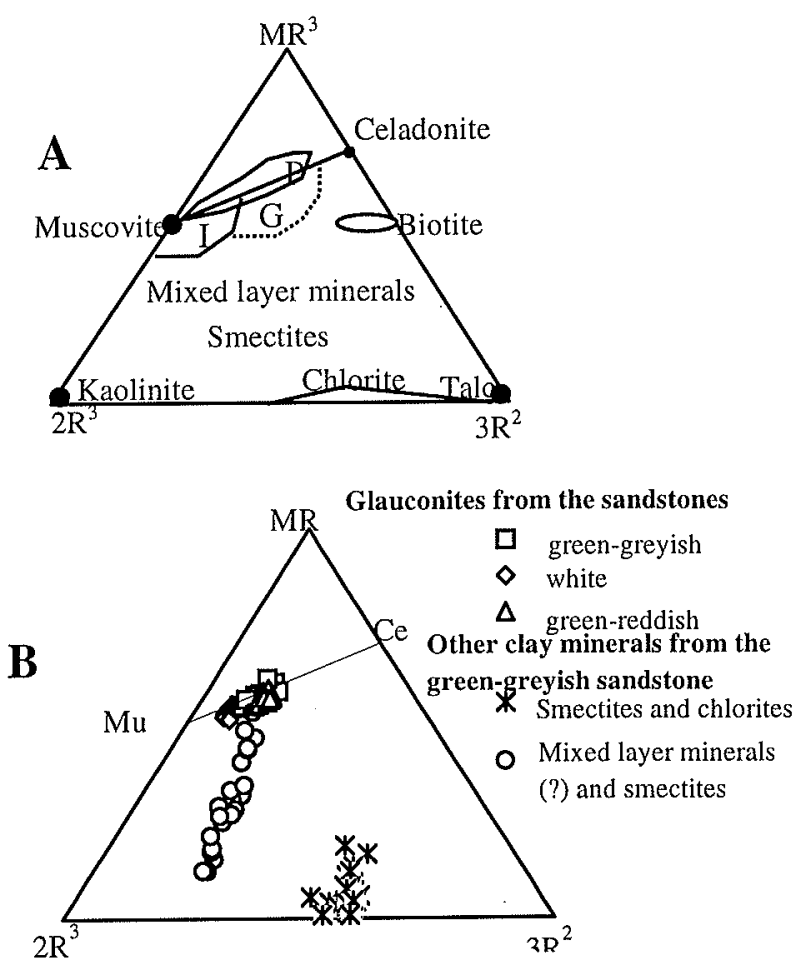

Figure 4-(A) - Compositional fields of some phyllossilicates (Velde 1985a). I: illite; G: glauconite; $P$; phengite. (B) - Glauconite from the white sandstone concentrate in the illite field. The glauconite from the green-reddish and the green-grayish sandstone plot in the glauconite field. Glauconite from the green-grayish sandstone show two trends: towards phengite + illite and towards mixed-layer minerals (or intergrowths) and dioctahedral smectite. Chlorite and trioctahedral smectite are associated to glauconies in greengrayish sandstone. Structural formulae were calculated assuming that all the iron as $\mathrm{Fe}^{+3}$ and $\mathrm{Fe}^{+2}$ for the dioctahedral and trioctahedral smectites, respectively. This may explain the gap in the diagram.

illitic composition, as a consequence of replacement of $\mathrm{Al}$ for $\mathrm{Si}$ in tetrahedral position and for Fe-Mg in the octahedral site. In the second trend, two distinct poles are found: glauconite and chlorite. Between them intermediate values have octahedral sum between $4.5-5.8$ 
(calculated as mica) and high $\mathrm{Fe}-\mathrm{Mg}$ contents, while $\mathrm{Si}$ and total alkalis are both lower than glauconite (table 2). These compositionally intermediate results fall in a zone in the MR diagram, which correspond to smectite and mixed-layer minerals. Smectite, but not the mixed-layer minerals, is identified by X-ray patterns. So, the intermediate composition can represent an intimate intergrowth with glauconite, smectite and chlorite. Chlorites have a trioctahedral character with a low vacancy in octahedral sites, and have $\mathrm{Fe}$ and $\mathrm{Mg}$ contents higher than aluminum.

Chemical composition of the whole rock is quite different from one rock to another (Table 2). Si and Al contents in the whole rock show an inverse relationship with the Si-Al glauconite composition. The white sandstone, which is the most Si-rich and the most Al-poor rock, has also the most Si-poor, most Al-rich glauconite. The green-reddish sandstone is the less Si-rich rock, but contains the most siliceous glauconite. This rock is also the Al-richest sandstone and contains the less Al-rich glauconite. The whole rock contents of $\mathrm{Fe}-\mathrm{Mg}$ show a direct relationship with octahedral composition of the glauconies. The green-reddish $\mathrm{Fe}, \mathrm{Mg}$-richest sandstone also contains the $\mathrm{Fe}, \mathrm{Mg}$-richest glauconite. The K-contents in the rock and glauconite show no relation. The green-grayish sandstone is the only rock that presents a $\mathrm{Fe}^{2+} / \mathrm{Fe}^{3+}$ ratio more than 1 . This chemical feature is invoked to explain the chlorite presence only in this rock.

DISCUSSION Some workers (Cimbálníková 1971, Strickler and Ferrel 1990) have shown an inverse correlation between $\mathrm{K}$ and $\mathrm{Al}$ contents of glauconite and their direct ratio of $\mathrm{K}$ and $\mathrm{Fe}$ contents.

The present study shows that the Paranoá glauconites are aluminous and high $\mathrm{K}$-content species, with the same low-expandable structure, characteristic of a high-grade diagenetic rock (Hower 1961, Srodon and Eberl 1984). However, the distribution of tetrahedral and octahedral charges, as well as the relationships between glauconites, illite, chlorite and calcite, vary from one rock to another.

Glauconite compositionally similar to a ferric illite has been reported in ancient rocks by Berg-Madsen (1983), Dasgupta et al. (1990), Ireland et al. (1983). While the two former authors attributed this composition to depositional conditions, the later assumed that illitization of glauconite is an effect of burial diagenesis, by very extensive Al substitution for $\mathrm{Si}$ and for $\mathrm{Fe}-\mathrm{Mg}$. In the Paranoá Group, different glauconitic sandstones are interpreted as lateral facies in a shelf environment (Guimarães 1997).

In the white sandstone, glauconites appear as ferric illite, as a product of diagenetic illitization, and the whole rock analysis shows an iron-magnesium poor rock composition. Released iron and magnesium could have been transferred to another level, by intensive pore water circulation, and confirmed by abundant quartz overgrowths.

In green-grayish sandstone, there's a trend from glauconite to illite as an effect of $\mathrm{Al}$ substitution for $\mathrm{Si}$ and $\mathrm{Fe}-\mathrm{Mg}$. The iron released by illitization would enter either in the formation of opaque minerals, or together with $\mathrm{Mg}$ in the constitution of chlorite.

The green-reddish sandstone does not show ferric illite. Apparently the very high $\mathrm{Fe}$-content and the low porosity of the rock avoided $\mathrm{Al}$ substitution for $\mathrm{Si}$ and $\mathrm{Fe}-\mathrm{Mg}$.

Presence or absence of chlorite in the compositionally similar shales having experienced the same burial diagenesis was explained as an effect of the oxidation state of iron (Velde 1985b). Seen in MR diagram, the bulk composition of the clay system can be placed on R2 or R3 field according the oxidation state of the iron (fig. 4). Thus, assemblages of illite + smectite where iron is ferric, can be replaced by illite + chlorite assemblages, if the iron is reduced.

In the Paranoá glauconitic sandstones, the glauconite + smectites + chlorite assemblage is found only in the green-grayish sandstone. This is the only rock that shows a $\mathrm{Fe}^{2+}$ content higher than $\mathrm{Fe}^{3+}$ and is also the only one where carbonates are presents.

Chlorites associated to glauconite and carbonate were reported in Helvetic Alps, in non-metamorphic and very-low-grade-metamorphic rocks (Köester and Kohler 1973, Frey and Hunziker 1973). Analyses from these rocks presented by the latter authors indicate also a high $\mathrm{Fe}^{2+} / \mathrm{Fe}^{3+}$ ratio.

The presence of carbonate plays a role in the iron oxidation state change. It consequently influences the bulk composition of the system and allows the formation of trioctahedral minerals, such as chlorites, under diagenetic/very low metamorphic conditions.

Green-reddish and white sandstones apparently were always under oxidant conditions, iron being often ferric. Even in a Mg-rich rock, as the green-reddish sandstone, a high iron ferric content avoids chlorite formation.

CONCLUSIONS The study of the three series of glauconites indicates that during diagenesis/anchimetamorphism events in the Paranoá Group:

1- Glauconites belonging to different rocks, which have undergone the same P-T conditions, reached similar crystallographic structures, but distinct chemical composition.

2- Chemical composition and mineralogical evolution of glauconites are lithologically dependent.

3- Illitization of glauconite during diagenesis promotes $\mathrm{Al}$ substitution for $\mathrm{Si}$ and $\mathrm{Fe}$. This substitution is conditioned either by intensive leaching under oxidant conditions (as in the white sandstone), or by reduction of iron under moderate conditions (as in the greengrayish sandstone). Excess of iron oxides prevents illitization of glauconites, as seen in green-reddish sandstone.

4- Glauconite + chlorite assemblages can be expected if the $\mathrm{Fe}^{2+} / \mathrm{Fe}^{3+}$ ratio (or $\mathrm{R} 2 / \mathrm{R} 3$ ) in the rock is higher than 1 . This ratio takes place more easily where carbonates are present.

5- Chemical composition of buried glauconites cannot be adopted as a trustful criterion for discrimination of paleodepositional facies and diagenetic conditions, since it is strongly influenced by the lithology.

Acknowledgements This work was funded by a grant from CAPES (Ministério de Educação do Brasil), to E. M. Guimarães, by Universidade de Brasília and PADCT that supported field work and petrographic studies, as well as by École Normale Superiéure (Laboratoire de Géologie) that provided X-ray, wet-chemical and microprobe analyses. To two anonymous referees of $R B G$ for the critical review of the manuscript.

\section{References}

Amorosi A. 1995. Glaucony and sequence stratigraphy: a conceptual framework of distribution in siliciclastic sequences. Jour: Sed. Research, B65:419-425.

Bentor Y.K. \& Kastner M. 1965. Notes on the mineralogy and origin of glauconite. Jour: Sedim. Petrol., 35:155-166.

Berg-Madsen V. 1983. High-alumina glaucony from the middle Cambrian of Öland and Bornholm, southern Baltoscandia. Jour: Sed. Petrol., 53: 875-893.

Burst J. F. 1958. Mineral heterogeneity in "glauconite" pellets. Am. Mineral., 43:481- 497. Cimbälnikovä A. 1971. Chemical variability and stuctural heterogeneity of glauconites. Am. Mineral., 56:1385-1392.

Dasgupta S., Chaudhuri A., Fukuoka M. 1990. Compositional characteristics of glauconitic alterations of K-feldspar from India and their implications. Jour: Sed. Petrol., 60:277287.

Frey $M$. and Hunziker J.C. 1973. Progressive niedriggradige Metamorphose Glaukonitfürender Horizonte in den helvetischen Alpen der Oatschweiz. Contr. Mineral. Petrol., 39:185-218.

Guimarães E.M. 1997. Estudos de proveniência e diagênese, com ênfase na caracterizaçáo dos filossilicatos dos grupos Paranó e Bambuí, na região de Bezerra-Cabeceiras, GO. Unpublished PhD thesis, Universidade de Brasília, Brasil. $260 \mathrm{pp}$.

Hower J. 1961. Some factors concerning the nature and origin of glauconite. Am. Mineral, 46:313-334.

Ireland B.J., Curtis C.D., Whitteman J. A. 1983. Compositional variation within some glauconites and illites and implications for their stability and origins. Sedimentology, 30:769-786.

Köester V.H. M. \& Kohler E.E. 1973. Sedimentpetrographische und mineralogische Untersuchungen an glaukonitfuhrenden Kreidegesteinen Bayerns. Geol. Rundschau, $62 \cdot 52.1-535$
Millot G. 1964. Géologie des Argiles. Masson, Paris. 499 pp.

Odin G. S. 1975. De glauconarium constitutione, origine, aetateque. Thése Doctorat d'Etat, Un.Paris VI, $280 \mathrm{pp}$.

Odin G. S. \& Matter A.. 1981. De glauconarium origine. Sedimentology, 28:61 1-641.

Odin G. S. (ed.) 1988. Green Marine Clays. Elsevier, $446 \mathrm{pp}$

Porrenga D. H. 1967. Glauconite and chamosite as depth indicators in the marine environment. Marine Gerol., 5:495-501.

Reynolds Jr, R.C. 1985. NEWMOD C a computer program for the calculation of one dimensional diffraction patterns of mixed-layered clays. R.C. Reynolds Jr.., 8 Brook Dr., Hanover, New Hamphire.

Srodon J. \& Eberl D. 1984. Illite. In: Bailey, S.W. (ed.) Micas. Mineralogical Society of America, Reviews in Mineralogy, 13:495-544.

Strickler M.E. \& Ferrell Jr. R.E. 1990 . Fe substitution for Al in glauconite with increasing diagenesis in the first Wilcox sandstone (Lower Eocene), Livingston Parish, Lousiana. Clays and Clay Minerals, 38:69-76.

Velde B. 1985a. Clay minerals: a Physical Chemical Explanation of their Occurrence. Developments in Sedimentology, 40. Elsevier, Amsterdam. $427 \mathrm{pp}$.

Velde B 1985b. Possible chemical controls of illite/smectite composition during diagenesis. Mineral. Mag., 49:387-391. 